\title{
Pengaruh Lembaga Pendidikan dan Penanggulangan Bencana Daerah terhadap Partisipasi Pelatihan Bencana Rumah Tangga
}

\author{
Aditya Wahyu Dewanggajati; Sartika Djamaluddin \\ Program Studi Magister Perencanaan dan Kebijakan Publik, Universitas Indonesia \\ Jl. Salemba Raya No.4 Jakarta Pusat 10430 \\ aditya.dewanggajati@gmail.com
}

Article received: July 2020; revised: October 2020 ; accepted : January 2021

DOI : 10.17977/um025v5i12020p29

\begin{abstract}
Disaster coping management is important to be well managed by the government and all stakeholders because Indonesia is a disaster-prone area. Disaster risk reduction (DRR) is needed because of the number of disasters occurring recently have serious impacts on the economy, social and environment. This study aims to look at the effect of education institution and regional disaster management institutions (BPBD) on household participation of disaster training as an effort of DRR. Literature also revealed that regional and households characteristics have an important role in implementing DRR. The design of this study uses quantitative logit regression analysis using secondary data from 297,276 household respondents from the 2017 National Socio-Economic Survey (SUSENAS). The results showed the disaster institutions at the district level, secondary education and universities has a significant impact and was able to provide an increase in probability of household disaster training participation.
\end{abstract}

Keywords: disaster, education, BPBD, disaster training, logit

\begin{abstract}
Abstrak: Manajemen penanggulangan bencana merupakan hal yang penting dikelola dengan baik oleh pemerintah dan semua elemen masyarakat karena Indonesia memiliki wilayah rawan bencana. Pengurangan risiko bencana (PRB) diperlukan mengingat banyaknya kejadian bencana dewasa ini berdampak cukup serius pada perekonomian, sosial maupun lingkungan hidup. Penelitian ini bertujuan untuk melihat pengaruh lembaga pendidikan serta keberadaan lembaga penanggulangan bencana daerah terhadap partisipasi pelatihan atau simulasi bencana rumah tangga sebagai upaya PRB. Literatur juga mengungkapkan bahwa karakteristik daerah memiliki peran penting dalam implementasi PRB secara optimum. Desain penelitian ini menggunakan analisis kuantitatif regresi logit dengan memanfaatkan data sekunder 297,276 responden rumah tangga dari Survei Sosial Ekonomi Nasional (SUSENAS) tahun 2017. Hasil menunjukan keberadaan lembaga penanggulangan bencana $\mathrm{kab} /$ kota dan lembaga pendidikan di daerah berupa pendidikan menengah, perguruan tinggi memiliki pengaruh signifikan dan dapat memberikan peningkatan terhadap kemungkinan partisipasi pelatihan kebencanaan rumah tangga.
\end{abstract}

Kata Kunci: bencana, pendidikan, BPBD, pelatihan bencana, logit

Indonesia merupakan negara yang memiliki kerentanan yang cukup tinggi terhadap bencana alam dikarenakan kondisi geografisnya yang menjadi titik pertemuan lempeng-lempeng tektonik. Sejarah menunjukan bahwa Indonesia pernah mengalami sejumlah bencana dengan skala yang cukup besar. Dalam periode 1984-2013 Indonesia pernah mengalami 325 kejadian bencana alam yang menelan 
190.794 korban jiwa, sedangkan 20 juta penduduk terpapar bencana serta kerugian ekonomi sebesar US\$ 26 Milyar (Priester, 2016). Gambar 1 menyajikan tren kerusakan fasilitas akibat bencana, dimana selama tahun 2016, 2.348 bencana menyebabkan korban jiwa 521 orang meninggal dunia, 2.678 lukaluka dan 3,16 juta orang mengungsi. Selain itu kerusakan terjadi pada 48.363 rumah dan 2.323 fasilitas umum (BNPB). Kuantitas kerusakan fisik terbanyak terjadi pada kerusakan fasilitas pendidikan. Lebih lanjut, Amri (2017) menjelaskan dalam 15 tahun terakhir sebanyak 46.648 sekolah terdampak bencana skala menengah dan besar.

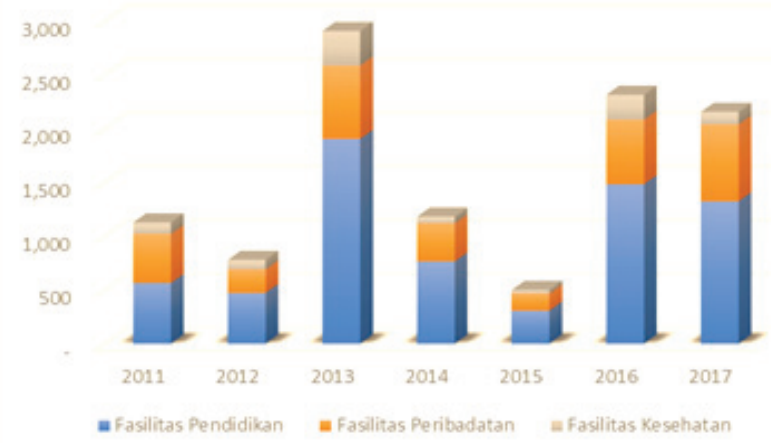

Gambar 1. Tren Kerusakan Fasilitas akibat Bencana di Indonesia Tahun 2011-2017

Sumber: BNPB, diolah

Strategi pengurangan risiko bencana (PRB) diperlukan agar dampak berupa korban jiwa maupun risiko dampak ekonomi, sosial dan lingkungan suatu daerah terdampak bencana dapat dikurangi (Narayan, 2003 dan Cashin \& Sosa, 2013). Kerangka PRB merupakan proses substansial penting yang dapat mewujudkan resiliensi daerah dan masyarakat dalam menghadapi bencana (Magnus \& Per, 2012). Peningkatan resiliensi masyarakat terhadap bencana ini perlu dilakukan secara keseluruhan baik pada pada fase pra, saat terjadi dan pasca bencana dan memerlukan peran dari otorisasi pemerintah terutama pemerintah daerah (Wu, Takara, \& Yamashiki, 2012 dan Timothy, Dominelli, \& Jocelyn, 2017). Pengurangan risiko pra bencana menjadi perhatian khusus untuk mendukung pemulihan pada beberapa aspek ekonomi, layanan sosial maupun psikologis masyarakat terdampak bencana setelah terjadinya bencana (Erdik \& Goyet, 1991). Sementara itu upaya pengurangan risiko pasca bencana melalui ketahanan ekonomi dan sosial yang diperlihatkan dengan kekuatan kelembagaan diperlukan untuk mempersingkat periode pemulihan (Hosoya, 2016).

Penelitian ini akan membahas bagaimana pengaruh lembaga pendidikan dan keberadaan lembaga penanggulangan bencana daerah dalam memberikan kemungkinan partisipasi rumah tangga melakukan pelatihan atau simulasi bencana sebagai kerangka PRB dengan peningkatan resiliensi bencana masyarakat. Carter, (1983) mengungkapkan tujuan pelaksanaan pelatihan di masyarakat yaitu untuk meningkatkan kesiapsiagaan masyarakat akan bencana di level optimum. Hal ini dapat meningkatkan pengetahuan individu tentang program-program yang dimiliki pemerintah daerah dalam upaya penanggulangan bencana, cara terbaik untuk melindungi keluarga dan orang terdekat dalam menghadapi kejadian darurat serta bagaimana cara mendukung pemerintah sebagai relawan setelah terjadinya bencana. Pemerintah daerah sebagai peran kunci dalam peningkatan kesiapsiagaan masyarakat di wilayahnya memiliki beberapa keterbatasan dalam kapasitas keuangan maupun wewenang (Malalgoda dkk., 2010). Zubir \& Amirrol (2011) memberikan alternatif tambahan dalam kerangka pengurangan risiko tersebut melalui konsep partisipatif masyarakat adaptif. Hal ini mengungkapkan bahwa selain lembaga otoritas bencana, peran lembaga pendidikan sangat diperlukan sebagai ujung tombak penanaman keterampilan serta peningkatan partisipasi aktif masyarakat dalam manajemen penanggulangan bencana (Catangui, 2020).

\section{Pelatihan dan Simulasi Bencana}

Pelatihan dan simulasi bencana sebagai bagian dari pendidikan kebencanaan yang efektif merupakan tantangan tersendiri bagi pemerintah daerah maupun pemangku kepentingan lainnya seperti dinas 
pendidikan maupun lembaga pendidikan formal. Badan Nasional Penanggulangan Bencana (BNPB) sebagai lembaga yang memiliki otoritas dalam penanggulangan bencana nasional juga telah mengatur kerangka PRB di lembaga pendidikan melalui Perka BNPB No. 4 Tahun 2012 tentang Pedoman Penerapan Sekolah/Madrasah Aman dari Bencana. Untuk mencapai masyarakat yang tahan dari bencana diperlukan kerangka kerja penanggulangan bencan non-struktural yaitu peningkatan pengetahuan, sikap dan tindakan masyarakat melalui pendidikan dan pelatihan. Pendidikan bencana anak terdiri dari nilainilai dasar berupa perubahan budaya, berorientasi pemberdayaan, kemandirian, pendekatan berbasis hak, keberlanjutan, kearifan lokal, kemitraan dan inklusivitas.

Walz (1992) menyatakan bahwa pelatihan bencana harus dilaksanakan dengan keberlanjutan, berurutan dan terintegrasi. Keberlanjutan yang dimaksudkan merupakan pengaturan secara vertikal pada kegiatan pembelajaran kebencanaan bagi pendidik maupun peserta didik. Berurutan mendukung pengembangan peserta didik dari keterampilan dasar menjadi pengetahuan kemudian menuju sikap tangguh bencana. Integrasi merupakan pengaturan pembelajaran horizontal dimana pendidikan bencana dapat dilaksanakan secara luas. Tujuan peningkatan kecakapan masyarakat melalui pendidikan mitigasi bencana terbagi dalam beberapa sasaran (Suhardjo, 2011). Pertama, dengan sasaran anak-anak diharapkan pelatihan dapat mendorong kecakapan menolong diri sendiri. Kedua, sasaran remaja diharapkan dapat berpartisipasi aktif dalam PRB. Ketiga, dewasa diharapkan dapat berkoordinasi dengan upaya PRB pemerintah. Terakhir, pelaku pendidikan seperti guru, wali murid, pengawas, kepala sekolah dan dinas pendidikan serta tokoh masyarakat diharapkan dapat mendesiminasi usaha PRB.

\section{Lembaga Pendidikan Indonesia}

Lembaga pendidikan dalam suatu daerah perlu ikut andil dalam pelaksanaan PRB melalui pelatihan atau simulasi bencana. Peningkatan pengetahuan masyarakat akan bencana erat kaitannya dengan jumlah fasilitas lembaga pendidikan yang dimiliki di daerah masyarakat atau rumah tangga tinggal (Baytiyeh, 2015). Di Indonesia, tata kelola lembaga pendidikan mengalami dekonstruksi sesuai dengan Undang-undang No. 23 Tahun 2014 tentang Pemerintah Daerah. Undang-undang ini merupakan dasar peralihan pengalihan tanggungjawab urusan pendidikan pada pemerinah provinsi maupun pemerintah kabupaten/kota.

Perubahan kewenangan terjadi pada urusan pendidikan menengah yang semula menjadi kewenangan pemerintah kabupaten/kota beralih menjadi kewenangan pemerintah provinsi bersamasama dengan pendidikan khusus. Hal ini merupakan tindakan resentralisasi yang didasari oleh beberapa faktor terutama pada pemerataan kualitas pendidikan menengah karena merupakan jenjang untuk mempersiapkan peserta didik menjadi lebih kompetitif. Kebijakan ini mendapatkan pertentangan dari beberapa pihak yang kemudian mengajukan keberatan melalui gugatan kepada Mahkamah Konstitusi (MK). Potensi kreativitas daerah melalui pemerintah kabupaten/kota dikhawatirkan tidak berkembang dalam mengelola pendidikan menengah (Damayanti, 2017). Namun, gugatan kebijakan tersebut ditolak oleh MK. Kebijakan otonomi daerah yang berlaku pada urusan pendidikan diharapkan pemerintah daerah dapat bersungguh-sungguh dalam mengembangkan pendidikan di wilayahnya (Hidayat, 2016).

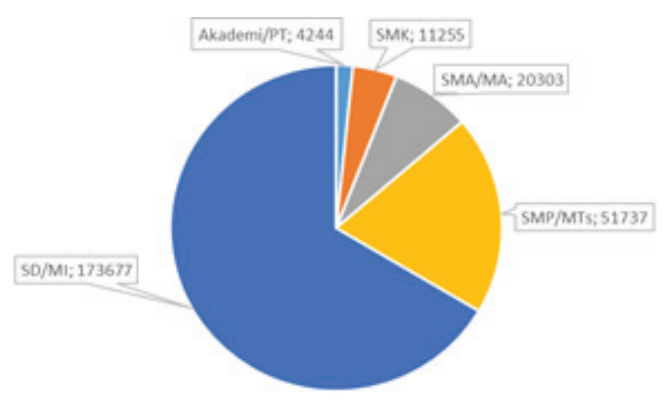

Gambar 2. Jumlah Lembaga Pendidikan di Indonesia

Sumber: BPS (Potensi Desa 2014), diolah 
Gambar 2 menyajikan tentang jumlah lembaga pendidikan di Indonesia berdasarkan data Potensi Desa 2014 yang merupakan publikasi dari BPS. Pemerintah Kabupaten/Kota memiliki kewenangan dalam pelaksanaan pendidikan tingkat SD/MI Negeri dan Swasta sebesar 173.677 unit dan tingkat SMP/ MTs Negeri dan Swasta sebesar 51.737 unit serta pendidikan anak usia dini dan nonformal. Pemerintah Provinsi memiliki kewenangan dalam pelaksanaan pendidikan di tingkat SMA/MA Negeri dan Swasta sebesar 20.303 unit, tingkat SMK Negeri dan Swasta sebesar 11.255 unit dan pendidikan khusus. Sementara itu, pemerintah pusat memiliki kewenangan dalam pelaksanaan pendidikan tinggi sebesar 4.244 unit.

\section{Lembaga Penanggulangan Bencana Daerah}

Implementasi pelatihan dan penyebaran informasi kebencanaan yang diprakasai pemerintah daerah secara efektif menjadi penting bagi Indonesia yang memiliki kerentanan tinggi akan bencana untuk meningkatkan resiliensi masyarakat (Mukhlis dkk, 2017). Dalam kaitannya, pemerintah daerah memiliki peran dan tanggungjawab dalam inisiasi manajemen PRB serta pengembangan resiliensi masyarakat dan wilayah terdampak (Malalgoda et al., 2010 dan Kusumasari \& Alam, 2012). Regulasi terkait bencana alam di Indonesia yaitu Undang- Undang Nomor 24 Tahun 2007 dan Peraturan Pemerintah Nomor 21 Tahun 2008 tentang Penanggulangan Bencana telah mengatur terkait kebijakan tata kelola kelembagaan bencana ke arah desentralisasi administrasi dengan dibentuk institusi Badan Penanggulangan Bencana Daerah (BPBD). Prinsip dasar dari kebijakan desentralisasi, yakni memberikan kewenangan yang lebih luas kepada daerah untuk melakukan inovasi. Hal ini juga didukung oleh sebagian besar literatur menyatakan bahwa desentralisasi akan meningkatkan pelayanan publik yang lebih efisien pemerintahan sentralisasi (Nazara, 2010).

Desentralisasi kelembagaan memiliki beberapa tujuan dalam PRB, pertama bertujuan untuk mendorong otoritas dan kapasitas daerah tentang pengetahuan manajemen bencana sesuai dengan tipe potensi bencana di daerah masing-masing dan pemerintah daerah dapat menyusun kebijakan yang sesuai dengan program PRB seperti peraturan pembangunan infrastruktur dan penggunaan lahan (Garschagen, 2016). Kedua, ketika bencana terjadi di wilayah yang sulit dijangkau, pemerintah daerah memiliki akses yang lebih baik dibandingkan dengan pemerintah pusat sehingga diharapkan dapat memberikan respon yang cepat (Ainuddin dkk., 2013). Namun, beberapa penelitian menunjukan desentralisasi menimbulkan beberapa permasalahan yaitu inisiatif pemerintah daerah rendah pada negara berkembang menyebabkan ketimpangan kemampuan daerah menjadi penyebab utama lemahnya penerapan desentralisasi sehingga mempengaruhi kinerja manajemen bencana daerah (Zhanghui \& Zhiming, 2011; Scott dkk., 2016).

Sejak tahun 2008, pemerintah kabupaten/kota mulai melakukan pembentukan BPBD di wilayah mereka dengan mengeluarkan peraturan daerah. Namun hingga 2017, masih terdapat 39 kabupaten/kota yang belum memiliki BPBD. Hal ini dikhawatirkan upaya PRB tidak berjalan dengan efektif.

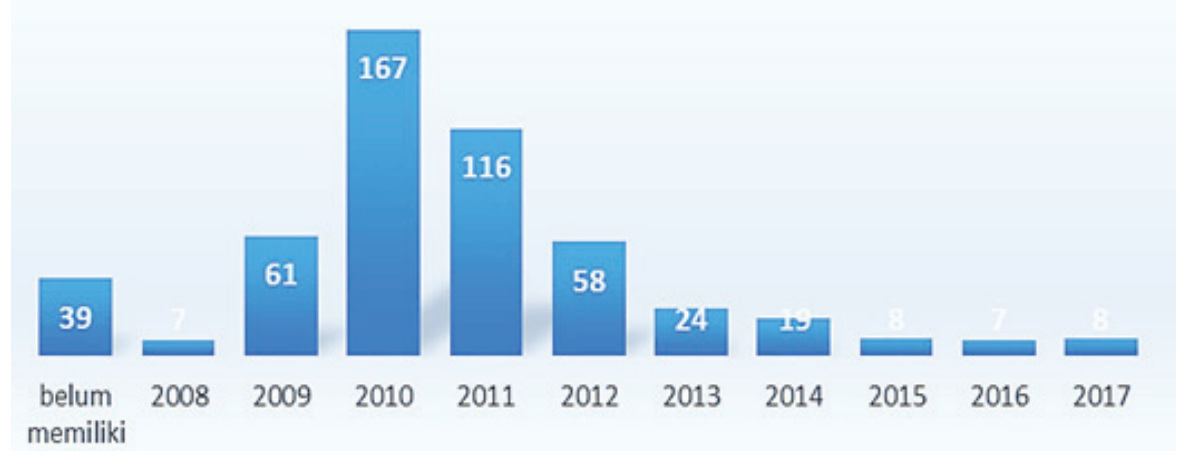

Gambar 2. Pembentukan BPBD kabupaten/kota berdasarkan Tahun Peraturan Daerah 


\section{METODE}

\section{Data}

Penelitian ini menggunakan data yang diperoleh dari pengumpulan data sekunder yang berasal dari berbagai sumber. Variabel utama dari penelitian ini menggunakan informasi dari kuesioner Susenas Maret 2017 yang merupakan data dari Badan Pusat Statistik dengan jumlah responden penelitian sebesar 297.276 rumah tangga. Variabel dependen dalam penelitian ini yaitu training yang merupakan dummy partisipasi anggota keluarga dalam satu rumah tangga pada pelatihan atau simulasi tentang penyelamatan bencana. Nilai 1 ketika anggota keluarga dalam rumah tangga pernah mengikuti pelatihan atau simulasi penyelamatan bencana, sedangkan nilai 0 untuk lainnya.

Variabel independen utama berupa kelembagaan penanggulangan bencana digambarkan dengan keberadaan lembaga penanggulangan bencana yaitu BPBD pada kabupaten/kota responden rumah tangga tinggal. Sementara itu, lembaga pendidikan digambarkan oleh jumlah lembaga pendidikan atau sekolah yang tersedia dalam satu kabupaten/kota. Pengaruh lembaga pendidikan didefinisikan dengan jumlah institusi pendidikan dasar dan menengah dalam $1 \mathrm{~km} 2$ serta jumlah perguruan tinggi dalam satu kabupaten/kota responden rumah tangga tinggal. Variabel independen lainnya yang digunakan dalam penelitian ini dijelaskan dengan rinci pada tabel 2. Variabel independen tersebut menggunakan data sekunder dari berbagai sumber antara lain BNPB, BPS, Dirjen Perimbangan Keuangan Kementerian Keuangan dan Kementerian Desa PDTT.

Tabel 1. Variabel Independen Penelitian

\begin{tabular}{|c|c|}
\hline Variabel & Deskripsi \\
\hline \multicolumn{2}{|c|}{ Independen Utama } \\
\hline \multicolumn{2}{|c|}{ Lembaga Penanggulangan Bencana Daerah } \\
\hline BPBD & $\begin{array}{l}\text { dummy keberadaan SKPD penanggulangan bencana kab/kota; } 1 \text { untuk RT } \\
\text { yang tinggal di kab/kota yang memiliki BPBD; } 0 \text { untuk lainnya. }\end{array}$ \\
\hline \multicolumn{2}{|c|}{ Lembaga Pendidikan } \\
\hline SDSMP & $\begin{array}{l}\text { jumlah institusi pendidikan setingkat SD/MI dan SMP/MTs (Negeri dan } \\
\text { Swasta) dibagi dengan luas daratan dalam satu kab/kota. }\end{array}$ \\
\hline SMASMK & $\begin{array}{l}\text { jumlah institusi pendidikan setingkat SMA/MA dan SMK (Negeri dan } \\
\text { Swasta) dibagi dengan luas daratan dalam satu kab/kota. }\end{array}$ \\
\hline PT & $\begin{array}{l}\text { jumlah institusi pendidikan setingkat Akademi/Perguruan Tinggi (Negeri } \\
\text { dan Swasta) dalam satu kab/kota. }\end{array}$ \\
\hline \multicolumn{2}{|c|}{ Karakteristik Daerah } \\
\hline risk & $\begin{array}{l}\text { dummy risiko bencana } \mathrm{kab} / \mathrm{kota} ; 1 \text { untuk RT yang tinggal di kab/kota yang } \\
\text { berisiko bencana tinggi; } 0 \text { untuk lainnya. }\end{array}$ \\
\hline PDRB & kontribusi PDRB kab/kota terhadap PDB nasional (persentase). \\
\hline disadv & $\begin{array}{l}\text { dummy klasifikasi daerah tertinggal; } 1 \text { untuk RT yang tinggal di kab/kota } \\
\text { yang bukan merupakan daerah tertinggal; } 0 \text { untuk lainnya. }\end{array}$ \\
\hline desakota & $\begin{array}{l}\text { dummy klasifikasi tempat tinggal; } 1 \text { untuk RT yang tinggal di perkotaan; } 0 \\
\text { untuk lainnya. }\end{array}$ \\
\hline \multicolumn{2}{|c|}{ Karakteristik Rumah Tangga } \\
\hline educ & $\begin{array}{l}\text { dummy ijazah/STTB tertinggi yang dimiliki kepala rumah tangga; } 1 \text { untuk } \\
\text { kepala rumah tangga yang merupakan lulusan lebih tinggi dari SMA sedera- } \\
\text { jad; dan } 0 \text { untuk lebih rendah dari SMA sederajat. }\end{array}$ \\
\hline PKH & $\begin{array}{l}\text { dummy rumah tangga menerima program keluarga harapan; } 1 \text { untuk rt yang } \\
\text { tidak pernah menerima } \mathrm{PKH} ; 0 \text { untuk lainnya. }\end{array}$ \\
\hline
\end{tabular}




\section{Metodologi Penelitian}

Model pada penelitian ini disusun untuk menentukan pengaruh kelembagaan penanggulangan bencana daerah dengan pembentukan BPBD Kabupaten/Kota dan lembaga pendidikan terhadap partisipasi pelatihan atau simulasi kebencanaan rumah tangga di Indonesia. Analisis dalam penelitian ini menggunakan regresi logistik binari dalam mengestimasi hipotesis pada model. Model logit merupakan metode regresi probabilitas non linier dimana variabel dependen adalah variabel dummy. Penelitian ini menggunakan model logit karena memiliki dua kategori dalam variabel dependen. Kategori pertama, yaitu $y=1$ untuk menandakan rumah tangga pernah mengikuti pelatihan/simulasi penyelamatan bencana alam. Kedua, yaitu $\mathrm{y}=0$ untuk menandakan rumah tangga tidak pernah mengikuti pelatihan/simulasi penyelamatan bencana alam. Dalam menginterpretasikan hasil dari regresi logit ini, penelitian ini menggunakan odds ratio yang merupakan ukuran kemungkinan suatu kejadian terjadi dan tidak terjadi. Odds ratio dapat menggambarkan kemungkinan kenaikan berapa kali lipat peluang variabel dependen 1 jika variabel independen beurbah sebesar nilai tertentu. Apabila dibangingkan dengan koefisien logit $(\beta)$, odds ratio akan bernilai $>1$ jika $\beta$ positif dan akan bernilai $<1$ jika $\beta$ negatif. Berikut model ekonometrika sederhana dalam penelitian ini.

$$
\begin{gathered}
\text { traini }=\beta 0+\beta 1 \text { bpbdi }+\beta 2 \text { sdsmpi }+\beta 3 \text { smasmki }+\beta 4 \text { pti }+\beta 2 \text { kontroldaerahi }+ \\
\beta 3 \text { kontrolrumahtanggai }+\varepsilon i
\end{gathered}
$$

Model ini menggunakan tiga spesifikasi ekonometri yaitu model pertama tanpa variabel kontrol, kedua menggunakan variabel kontrol karakteristik daerah dan yang ketiga ditambahkan dengan karakteristik rumah tangga.

\section{HASIL DAN PEMBAHASAN}

Hasil estimasi model menggunakan metode logit yang digambarkan pada Tabel 2 menunjukan bahwa terdapat tiga model ekonometrik robust. Model I menggambarkan pengaruh BPBD dan lembaga pendidikan terhadap pelatihan atau simulasi bencana tanpa variabel kontrol. Model II ditambahkan dengan variabel kontrol karakteristik daerah berupa risiko bencana, kontribusi PDRB pada PDB nasional, klasifikasi daerah tertinggal, dan klasifikasi pedesaan atau perkotaan. Model III ditambahkan karakteristik rumah tangga yaitu pendidikan terakhir kepala rumah tangga dan status kemiskinan melalui proksi penerima program keluarga harapan (PKH).

\begin{tabular}{|c|c|c|c|c|c|c|}
\hline \multirow{2}{*}{ Variabel } & \multicolumn{3}{|c|}{ Logit } & \multicolumn{3}{|c|}{ Odds Ratio } \\
\hline & I & II & III & I & II & III \\
\hline bpbd & $0.3504 * * *$ & $0.4040 * * *$ & $0.3949 * * *$ & $1.4196 * * *$ & $1.4977 * * *$ & $1.4842 * * *$ \\
\hline sdsmp & $-0.2879 * * *$ & $-0.2416 * * *$ & $-0.2086 * * *$ & $0.7498 * * *$ & $0.7853 * * *$ & $0.8117 * * *$ \\
\hline smasmk & $1.4168 * * *$ & $1.1770 * * *$ & $1.0304 * * *$ & $4.1239 * * *$ & $3.2450 * * *$ & $2.8022 * * *$ \\
\hline $\mathrm{pt}$ & $0.0064 * * *$ & $0.0086 * * *$ & $0.0071 * * *$ & $1.0064 * * *$ & $1.0087 * * *$ & $1.0071 * * *$ \\
\hline risk & & 0.0385 & 0.0508 & & 1.0392 & 1.0521 \\
\hline pdrb & & $-0.4030 * * *$ & $-0.3727 * * *$ & & $0.6682 * * *$ & $0.6888 * * *$ \\
\hline disadv & & $0.1144 * *$ & $0.1163 * *$ & & $1.1212 * *$ & $1.1233 * *$ \\
\hline desakota & & $0.7275 * * *$ & $0.6202 * * *$ & & $2.0699 * * *$ & $1.8593 * * *$ \\
\hline educ & & & $0.8003 * * *$ & & & $2.2263 * * *$ \\
\hline pkh & & & $-0.1613 * *$ & & & $0.8509^{*}$ \\
\hline cons, & $-4.59 * * *$ & $-5.05 * * *$ & $-5.09 * * *$ & $0.0101 * * *$ & $0.0064 * * *$ & $0.0061 * * *$ \\
\hline Pseudo R2 & 0.0093 & 0.0230 & 0.0316 & 0.0093 & 0.0230 & 0.0316 \\
\hline Prob $>$ chi 2 & 0.0000 & 0.0000 & 0.0000 & 0.0000 & 0.0000 & 0.0000 \\
\hline
\end{tabular}

Tabel 2. Hasil Regresi Logit dan Odds Ratio

Catatan: Seluruh hasil regresi logit menghasilkan intersep, namun tidak diinterpretasikan. Interpretasi hasil menggunakan odds ratio dengan signifikansi $* \mathrm{p}<0.05, * * \mathrm{p}<0.01, * * * \mathrm{p}<0.001$. 
Berdasarkan hasil regresi logit, hampir seluruh variabel independen dan kontrol memiliki pengaruh signifikan terhadap variabel dependen dengan tingkat signifikasi beragam yaitu $1 \%, 5 \%$ dan $10 \%$, namun variabel risiko bencana yang dikeluarkan oleh BNPB tidak memiliki signifikansi. Variabel BPBD, jumlah SMA/SMK sederajat per km2 dalam kab/kota, jumlah perguruan tinggi dalam kab/ kota, klasifikasi daerah tertinggal, klasifikasi pedesaan dan perkotaan serta pendidikan kepala rumah tangga memiliki pengaruh signifikan positif. Namun jumlah SD/SMP sederajat per $\mathrm{km} 2$ dalam kab/kota, kontribusi PDRB kabupaten/kota, dan status kemiskinan rumah tangga memiliki pengaruh signifikan negatif.

Variabel kontrol dalam penelitian ini menunjukan hasil yang beragam. Risiko bencana tidak memiliki hubungan signifikan pada kemungkinan rumah tangga berpartisipasi dalam pelatihan atau simulasi bencana, hal ini sesuai dengan penelitian sebelumnya yang menyatakan bahwa risiko tidak memiliki hubungan signifikan terhadap aktivitas mitigasi bencana (Hidayati, 2013). Variabel kontrol lainnya memiliki hubungan signifikan. Rumah tangga yang daerahnya bukan termasuk daerah tertinggal memiliki kemungkinan memperoleh pelatihan atau simulasi bencana sebesar 1,12 kali lipat dibandingkan dengan daerah tertinggal. Kemudian, rumah tangga yang tinggal di perkotaan 1,85 kali lipat dibandingkan dengan tinggal di daerah pedesaan serta rumah tangga yang kepala rumah tangga memiliki ijazah/STTB lebih tinggi dari SMA sederajat sebesar 2,22 kali lipat dibandingkan dengan kepala rumah tangga yang memiliki pendidikan lebih rendah dalam kemungkinan memperoleh pelatihan atau simulasi bencana. Sebaliknya, pdrb daerah yang tinggi dan status kemiskinan rumah tangga memiliki kemungkinan lebih rendah dalam memperoleh pelatihan atau simulasi bencana.

\section{Pengaruh Lembaga Penanggulangan Bencana Daerah terhadap Partisipasi Pelatihan dan Simulasi Bencana Rumah Tangga}

Hasil output odds ratio pada Tabel 2 didapatkan variabel independen utama BPBD memiliki nilai sebesar 1.4196 pada model I, 1.4977 pada model II dan 1.4842 pada model III, artinya menggunakan model II dan II angka ini dapat dimaknai dengan kabupaten/kota yang memiliki BPBD memiliki rumah tangga yang mendapatkan pelatihan dan simulasi penyelamatan bencana 1,5 lebih besar dibandingkan kabupaten/kota yang tidak memiliki BPBD. Hal ini sesuai dengan literatur bahwa kelembagaan penanggulangan bencana daerah dapat mendukung kegiatan PRB pada masyarakat melalui pelatihan bencana pada masyarakat. Hasil ini juga diperkuat dalam penelitian sebelumnya yang menyatakan bahwa kelembagaan penanggulangan bencana dapat mendorong terbitnya peraturan di daerah tersebut yang dapat menciptakan efektivitas dalam aktivitas PRB (Pathirage, Seneviratne, Amaratunga, \& Haigh, 2012). Peran pemerintah daerah melalui BPBD sebagai koordinator sangat diperlukan dalam pemenuhan kebutuhan masyarakat akan penanggulangan bencana melalui pelatihan atau simulasi kebencanaan.

\section{Pengaruh Lembaga Pendidikan terhadap Partisipasi Pelatihan dan Simulasi Bencana Rumah Tangga}

Lembaga pendidikan merupakan salah satu wadah yang sangat tepat dalam membangun kewaspadaan bagi peserta didik melalui pembelajaran kebencanaan untuk meningkatkan kesiapsiagaan masyarakat Indonesia. Pembelajaran membutuhkan proses yang terintegrasi untuk mencapai tujuan akhir yaitu perubahan perilaku secara permanen pada peserta didik. Beberapa tahapan pembelajaran dimulai dari pengetahuan dasar dan penguasaan keterampilan sebelum masuk pada materi yang lebih kompleks dengan melibatkan aspek kognitif dan psikomotorik secara menyeluruh diperlukan oleh peserta didik (Walz, 1992). Integrasi pembelajaran kebencanaan diharapkan dapat meningkatkan kesiapsiagaan peserta didik dalam menghadapi bencana. Pengetahuan peserta didik ini dapat membentuk budaya siaga bencana dalam keluarga, sehingga terjadi peningkatan resiliensi rumah tangga akan bencana.

Berdasarkan hasil regresi pada Tabel 2, hubungan lembaga pendidikan terhadap kemungkinan rumah tangga berpartisipasi dalam pelatihan atau simulasi bencana memiliki hasil yang berbeda tiap jenjangnya. Cakupan jumlah SMA/SMK sederajat dan Perguruan Tinggi dalam kabupaten/kota memiliki 
pengaruh signifikan positif sementara jenjang pendidikan dasar memiliki hasil yang berlawanan. Semakin bertambah cakupan jumlah sekolah pada jenjang pendidikan setingkat SMA/SMK dalam satu kilometer persegi maka semakin besar kemungkinan rumah tangga berpartisipasi dalam pelatihan atau simulasi bencana. Saat ini pemerintah telah memiliki fokus dalam PRB di wilayah sekolah pada jenjang SMA/SMK dengan Sekolah Madrasah Aman Bencana (SMAB). Pengetahuan dan pemahaman terkait kebencanaan peserta didik setingkat SMA/SMK dapat ditingkatkan melalui literasi geografi dan aktivitas dalam ruang kelas dalam pendidikan formal (Kamil dkk., 2020). Namun komitmen pemerintah daerah akan program SMAB di Indonesia masih sangat rendah dilihat dari kebijakan di tingkat daerah yang mendukung penerapan SMAB di daerah masing-masing.

Hasil pada Tabel 2 juga menunjukan bahwa semakin bertambah jumlah perguruan tinggi maka semakin besar kemungkinan rumah tangga berpartisipasi dalam pelatihan atau simulasi bencana. Hal ini mendukung penelitian sebelumnya yang menyatakan bahwa peserta didik di jenjang perguruan tinggi di Malaysia memiliki pengetahuan tentang bencana terkait kesiapsiagaan dan tanggapan berada pada tingkat memuaskan, hal ini diharapkan dapat membantu masyarakat pada saat bencana terjadi untuk PRB (Nifa dkk., 2018). Chen, Yu, \& Chen (2012) juga menyatakan bahwa peran lembaga pendidikan di tingkat kabupaten/kota dapat dilakukan dengan pelaksanaan pelatihan dan pendidikan pencegahan bencana untuk guru atau yang sering disebut teacher-training program. Sementara itu, lembaga pendidikan perguruan tinggi diharapkan dapat memperkuat pengetahuan pencegahan dan mempromosikan kesadaran bencana berbasis sekolah yang diharapkan dapat disebarluaskan ke masyarakat. Praktik pemberdayaan masyarakat terkait bencana melalui perguruan tinggi telah dilakukan melalui kegiatan Kuliah Kerja Nyata $(\mathrm{KKN})$.

Namun, hasil penelitian menunjukan hal berlawanan untuk lembaga pendidikan jenjang SD/ SMP sederajat. Semakin bertambah jumlah SD/SMP sederajat dalam satu kilometer persegi maka semakin kecil kemungkinan rumah tangga berpartisipasi dalam pelatihan atau simulasi bencana. Hasil ini didukung oleh penelitian sebelumnya yaitu penggabungan sekolah dasar dapat meningkatkan efektivitas dan efisiensi kegiatan pembelajaran serta motivasi para guru (Setiawati, 2018). Informasi lain mengungkapkan bahwa setengah dari peserta didik sekolah dasar tidak mengetahui bahwa daerah mereka termasuk ke dalam daerah yang memiliki risiko tinggi akan bencana dan memiliki informasi yang kurang tepat terkait bencana (Kirikkaya dkk., 2011). Pengetahuan siswa di tingkat sekolah dasar akan mitigasi bencana perlu peningkatan yang lebih untuk menghindari dampak yang lebih besar akan bencana (Pahleviannur, 2019). Pelatihan kepada peserta didik sekolah dasar dapat meningkatkan pemahaman tentang pentingnya penyelamatan bencana bagi mereka. Indriasari (2018) menekankan pelatihan penyelamatan bencana atau simulasi pada jenis bencana gempa bumi memberikan pengaruh positif pada kesiapsiagaan anak. Penelitian ini dilakukan dengan metode kuesioner pada 31 responden siswa sekolah dasar.

Saat ini pemerintah telah menyusun beberapa program yang melibatkan lembaga pendidikan terkait pembelajaran kebencanaan. Program Sekolah Siaga Bencana (SSB) dari jenjang pendidikan anak usia dini hingga jenjang setingkat SMA/SMK. Susanti dkk. (2014) melakukan penelitian terkait implentasi SSB pada sekolah dasar rintisan program mendapatkan hasil bahwa SSD dapat meningkatkan kesiapsiagaan komunitas sekolah dalam menghadapi bencana. Selain itu pemerintah melalui BNPB juga mengeluarkan pogram Satuan Pendidikan Aman Bencana yang memiliki konsep dan fokus pada anak-anak agar dapat berpartisipasi secara aktif dengan kapasitasnya masing-masing. Tiga komponen utama yaitu fasilitas sekolah aman, manajemen bencana di sekolah dan pendidikan pencegahan dan PRB (Amri, 2017).

Meskipun pemerintah dan lembaga yang bergerak di bidang PRB mengklaim bahwa pengetahuan tentang kebencanaan telah dimasukan ke dalam kegiatan pendidikan, masih terdapat kesenjangan pengetahuan peserta didik terhadap pengetahuan bencana (Bramasta, D., \& Irawan, 2020 dan Kamil dkk., 2020). Apabila kegiatan pelatihan hanya dilakukan pada beberapa event tanpa melibatkan semua komponen dan tahap yang ada, hasil yang maksimal dari pembelajaran sulit untuk tercapai. Semua 
pemangku kepentingan di Indonesia perlu untuk menambahkan kesadaran akan risiko bencana yang tinggi di Indonesia dengan membangun pelatihan kebencanaan di lingkungan sekolah sebagai landasan utama dan sumber pengetahuan bagi masyarakat Indonesia.

Berdasarkan hasil penelitian, lembaga pendidikan di Indonesia perlu meningkatkan kepedulian terhadap aktivitas PRB melalui pelatihan dan simulasi bencana kepada peserta didik terutama pada level pendidikan dasar. Kegiatan pelatihan bencana pada peserta didik anak diperlukan untuk meningkatkan kecakapan anak menolong diri sendiri dan sebagai dasar pendidikan anak dalam menghadapi bencana. Pelatihan kebencanaan di lingkungan sekolah diharapkan dapat meningkatkan pemahaman pada tahapan sebelum terjadi bencana, pada saat terjadi bencana dan setelah terjadi bencana (Bramasta, D., \& Irawan, 2020). Strategi PRB di lingkungan sekolah dapat dilakukan melalui pegembangan kurikulum pendidikan bencana dan kolaborasi institusi terkait.

Kurikulum bencana memerlukan beberapa hal yang perlu diperhatikan yaitu pemberdayaan kelembagaan dan komunitas sekolah, integrasi materi PRB ke dalam intra atau ekstra kurikuler serta membangun jaringan antar pihak untuk mendukung pelaksanaan kurikulum PRB di sekolah (Honesti \& Djali, 2012). Konsep pelatihan kebencanaan di lingkungan sekolah dapat berisi beberapa materi yaitu peningkatan awareness peserta didik akan ancaman bencana, pengetahuan dasar tentang risiko bencana di lingkungan sekolah dan daerah tempat tinggal, pemahaman jalur evakuasi dan kemampuan penggunaan alat-alat penyelamatan bencana serta kemampuan menyebarkan informasi kebencanaan pada orang terdekat. Pendekatan yang digunakan dalam pelatihan kebencanaan di sekolah disesuaikan dengan jenjang lembaga pendidikan tersebut.

Program pelatihan kebencanaan sebaiknya disajikan berdasarkan karakteristik komunitas, kondisi geografis dan melibatkan stakeholders yang ada pada lingkungan sekolah. Pelatihan kebencanaan yang diintegrasikan ke dalam kurikulum sekolah memiliki beberapa tantangan yang akan dihadapi seperti konsep pembelajaran yang berbeda-beda sesuai dengan karakteristik daerah, membutuhkan waktu yang lama dalam pengembangan dan penyempurnaan kurikulum, kendala teknis dalam implementasi serta keberlanjutan di masa yang akan datang (Betty dkk., 2010). Namun, Maknun (2015) mengembangkan perangkat PMBBKL (Pembelajaran Mitigasi Bencana Berorientasi Kearifan Lokal) yang dikembangkan dalam pelajaran IPA. Kearifan lokal dalam penerapan pemahaman mitigasi bencana dapat dilaksanakan dengan komprehensif dan terintegrasi sehingga dalam mengambil suatu keputusan solusi penanggulangan bencana yang tepat dan sesuai dengan karakteristik daerah.

Kolaborasi antar lembaga juga diperlukan agar program pelatihan bencana dapat dilakukan secara komprehensifdan terintegrasi bersama-sama dengan pengembangan kurikulum(Bae, 2015). Pengetahuan dasar kebencanaan dapat diperoleh melalui lembaga penanggulangan bencana daerah dan akademisi. Sementara itu, lembaga pendidikan dan lembaga terkait lainnya diperlukan sebagai elemen penting yang memiliki jaringan luas terhadap informasi kedaerahan dan karakteristik masyarakat. Kolaborasi BPBD, lembaga pendidikan, akademisi dan lembaga terkait lainnya diharapkan dapat mewujudkan peningkatan penanggulangan bencana yang berkelanjutan serta memanfaatkan sumber daya yang ada di daerah sebagai wujud optimalisasi PRB.

\section{SIMPULAN}

Berdasarkan analisis kuantitatif yang dilakukan, maka kesimpulan terkait dengan hasil penelitian memperlihatkan bahwa: (1) kelembagaan penanggulangan bencana daerah berupa keberadaan BPBD di kabupaten/kota memiliki pengaruh positif signifikan secara statistik terhadap kemungkinan partisipasi pelatihan dan simulasi bencana rumah tangga; (2) lembaga pendidikan menengah serta perguruan tinggi di suatu kabupaten/kota memiliki pengaruh positif signifikan secara statistik terhadap kemungkinan partisipasi pelatihan dan simulasi bencana rumah tangga, namun lembaga pendidikan dasar yang digambarkan melalui proksi jumlah SD/SMP pada kabupaten/kota per km2 memiliki pengaruh negatif secara statistik terhadap kemungkinan partisipasi pelatihan dan simulasi bencana rumah tangga. Hasil 
ini menunjukan bahwa manajemen penanggulangan bencana di Indonesia memerlukan peran BPBD di tingkat daerah dalam upaya PRB di level masyarakat. Intervensi pemerintah daerah melalui BPBD dalam penyediaan fasilitas yang berkaitan dengan kebencanaan diperlukan akibat besarnya kemungkinan dampak yang dirasakan akibat bencana. Selain itu peningkatan jumlah lembaga pendidikan di level SMA/ SMK dan perguruan tinggi serta penggabungan lembaga pendidikan menengah akan meningkatkan kemungkinan partisipasi pelatihan dan simulasi bencana rumah tangga. Peran pemangku kepentingan pendidikan seperti peserta didik, pendidik dan profesional lainnya, orang tua, organisasi non-pemerintah juga diperlukan dalam meningkatkan aktivitas PRB di masyarakat.

\section{DAFTAR RUJUKAN}

Ainuddin, S., Aldrich, D. P., Routray, J. K., Ainuddin, S., \& Achkazai, A. (2013). The need for local involvement: Decentralization of disaster management institutions in Baluchistan, Pakistan. International Journal of Disaster Risk Reduction, 6, 50-58. https://doi.org/10.1016/j.ijdrr.2013.04.001.

Amri, A. (2017). Pendidikan Tangguh Bencana: Mewujudkan Satuan Pendidikan Aman Bencana di Indonesia.

Bae, Y. (2015). Decentralization and collaborative disaster governance: Evidence from South Korea. Habitat International, 52, 50-56.

Baytiyeh, H. (2015). Developing effective earthquake risk reduction strategies: The potential role of academic institutions in Lebanon. Prospects, 45(2), 245-258. https://doi.org/10.1007/s11125-015-9344-3.

Betty, P., Maida, C. A., Steinberg, A. M., Beaton, R. D., Pynoos, R. S., Fairbank, J. A., .. Kurklinsky, A. K. (2010). Enhancing national capacity to conduct child and family disaster mental health research. Nursing Education Perspectives, 31(4), 237-241.

Bramasta, D., \& Irawan, D. (2020). Mitigasi Bencana Gunung Meletus di Sekolah Rawan Bencana. Publikasi Pendidikan, 10(2)(24), 154-159.

Carter, W. (1983). Counter $\square$ disaster training in developing countries. Disasters, 7(1), 34-36. https://doi. org/10.1111/j.1467-7717.1983.tb00785.x.

Cashin, P., \& Sosa, S. (2013). Macroeconomic fluctuations in the Eastern Caribbean: The role of climatic and external shocks. Journal of International Trade and Economic Development, 22(5), 729-748. https://doi.org /10.1080/09638199.2011.599854.

Catangui, M. J. B. (2020). Customizing school-based disaster risk reduction and management capability. Journal of Critical Reviews, 7(11), 175-180. https://doi.org/10.31838/jcr.07.11.28.

Chan, N. W., Roy, R., Lai, C. H., \& Tan, M. L. (2019). Social capital as a vital resource in flood disaster recovery in Malaysia. International Journal of Water Resources Development, 35(4), 619-637.

Chang, S., Wang, J., Lei, Y., Yu, H., \& Li, Q. (2012). Training programs for risk reduction of Typhoon disaster chains in Southeast coastal region of China. Proceedings of the 4th International Disaster and Risk Conference: Integrative Risk Management in a Changing World - Pathways to a Resilient Society, IDRC Davos 2012, $122-125$.

Chen, C. Y., Yu, K. H., \& Chen, M. Y. (2012). Planning of professional teacher-training program for disaster prevention education and executing efficiency evaluation. Disaster Prevention and Management: $A n$ International Journal, 21(5), 608-623.

Damayanti, S. N. (2017). Analisis Prospektif Kebijakan Pengalihan Kewenangan Pendidikan Menengah dari Pemerintah Kota Surabaya ke Pemerintah Provinsi Jawa Timur Berdasarkan UU No . 23 Tahun 2014 Tentang Pemerintahan Daerah. Kebijakan Dan Manajemen Publik, 5(3), 1-12.

Erdik, M. O., \& Goyet, C. de V. de. (1991). Training and education for disaster preparedness. In The Challenge of African Disasters. UN. Institute for Training and Research (UNITAR).

Garschagen, M. (2016). Decentralizing urban disaster risk management in a centralized system? Agendas, actors and contentions in Vietnam. Habitat International, 52, 43-49. https://doi.org/10.1016/j.habitatint.2015.08.030

Hidayat, N. (2016). Otonomi Daerah Dan Desentralisasi (Studi Pada Jenjang Pendidikan Menengah Dinas Pendidikan Kota Sawahlunto). Society, 4, 35-50.

Hidayati, U. (2013). Hubungan Antara Persepsi Risiko Dengan Kesiapsiagaan Bencana Pada Mahasiswa Unsyiah. ETD Unsyiah.

Honesti, L., \& Djali, N. (2012). Pendidikan Kebencanaan di Sekolah - Sekolah di Indonesia Berdasarkan Beberapa Sudut Pandang Disiplin Ilmu Pengetahuan. Jurnal Momentum, 12(1), 51-56. 
Hosoya, K. (2016). Recovery from natural disaster: A numerical investigation based on the convergence approach. Economic Modelling, 55, 410-420.

Indriasari, F. N. (2018). Pengaruh Pemberian Metode Simulasi Siaga Bencana Gempa Bumi terhadap Kesiapsiagaan Anak di Yogyakarta. Jurnal Keperawatan Soedirman, 11(3), 199.

Kais, S. M., \& Islam, M. S. (2016). Community capitals as community resilience to climate change: Conceptual connections. International Journal of Environmental Research and Public Health, 13(12). https://doi. org/10.3390/ijerph13121211

Kamil, P. A., Utaya, S., Utomo, D. H., Utaya, S., \& Utomo, D. H. (2020). Improving disaster knowledge within high school students through geographic literacy. International Journal of Disaster Risk Reduction, 43.

Kawawaki, Y. (2015). Building resilient coastal communities: Role of social capital. In Ozhan E. (Ed.), 12th International Conference on the Mediterranean Coastal Environment, MEDCOAST 2015 Volume 1 (pp. 3343). Mediterranean Coastal Foundation.

Kim, H., \& Marcouiller, D. W. (2016). Natural Disaster Response, Community Resilience, and Economic Capacity: A Case Study of Coastal Florida. Society and Natural Resources, 29(8), 981-997. https://doi.org/10.1080/08 941920.2015.1080336

Kirikkaya, E. B., Çakin, O., Imali, B., \& Bozkurt, E. (2011). Earthquake training is gaining importance: The views of 4 th and 5 th year students on earthquake. Procedia - Social and Behavioral Sciences, 15, 2305-2313. https://doi.org/10.1016/j.sbspro.2011.04.098

Kusumasari, B., \& Alam, Q. (2012). Bridging the gaps: The role of local government capability and the management of a natural disaster in Bantul, Indonesia. Natural Hazards, 60(2), 761-779. https://doi.org/10.1007/s11069011-0016-1

Magnus, H., \& Per, B. (2012). Seven elements for capacity development for disaster risk reduction. Proceedings of the 4th International Disaster and Risk Conference: Integrative Risk Management in a Changing World Pathways to a Resilient Society, IDRC Davos 2012, 286-289.

Maknun, J. (2015). Pembelajaran Mitigasi Bencana Berorientasi Kearifan Lokal Pada Pembelajaran IPA Di Sekolah Menengah Kejuruan. Jurnal Kajian Pendidikan, 5(1), 143-156.

Malalgoda, C., Amaratunga, D., \& Pathirage, C. (2010). Role of the local governments in disaster risk reduction. COBRA 2010: The Construction, Building and Real Estate Research Conference of the Royal Institution of Chartered Surveyors, 286-289.

Mukhlis, T., Syakur, T., Dharma, D. B., \& Anhorn, J. (2017). School preparedness and training for geological hazard mitigation: An example from Indonesia. WIT Transactions on the Built Environment, 173, $113-119$. https://doi.org/10.2495/DMAN170111

Narayan, P. K. (2003). Macroeconomic impact of natural disasters on a small island economy: Evidence from a CGE model. Applied Economics Letters, 10(11), 721-723. https://doi.org/10.1080/1350485032000133372

Nazara, S. (2010). Pemerataan Antardaerah sebagai Tantangan Utama Transformasi Struktural Pembangunan Ekonomi Indonesia Masa Depan. Jurnal Ekonomi Dan Pembangunan Indonesia, Vol. 11, pp. 83-98. https:// doi.org/10.21002/jepi.v11i1.183

Nifa, F. A. A., Lin, C. K., Abbas, S. R., \& Siong, E. S. (2018). A study of disaster and community risk knowledge among UUM students. AIP Conference Proceedings, 2016(September). https://doi.org/10.1063/1.5055408

Pahleviannur, M. R. (2019). Edukasi Sadar Bencana Melalui Sosialisasi Kebencanaan Sebagai Upaya Peningkatan Pengetahuan Siswa Terhadap Mitigasi Bencana. Jurnal Pendidikan Ilmu Sosial, 29(1), 49-55. https://doi. org/10.23917/jpis.v29i1.8203

Park, J. Y., Cho, J., \& Rose, A. (2011). Modeling a major source of economic resilience to disasters: Recapturing lost production. Natural Hazards, 58(1), 163-182. https://doi.org/10.1007/s11069-010-9656-9

Pathirage, C., Seneviratne, K., Amaratunga, D., \& Haigh, R. (2012). Managing disaster knowledge: Identification of knowledge factors and challenges. International Journal of Disaster Resilience in the Built Environment, $3(3), 237-252$.

Priester, L. De. (2016). An approach to the profile of disaster risk of Indonesia. Emergency and Disaster Reports, 3(2), 66.

Scott, Z., Wooster, K., Few, R., Thomson, A., \& Tarazona, M. (2016). Monitoring and evaluating disaster risk management capacity. Disaster Prevention and Management, 25(3), 412-422.

Setiawati, T. (2018). Program Penggabungan Sekolah Dasar (SD) Dalam Meningkatkan Efektivitas dan Efisiensi Penyelenggaraan Pendidikan. MENDIDIK: Jurnal Kajian Pendidikan Dan Pengajaran, 4(1), 55-62. https:// doi.org/10.30653/003.201841.43 
Suhardjo, D. (2011). Arti Penting Pendidikan Mitigasi Bencana Dalam Mengurangi Resiko Bencana. Jurnal Cakrawala Pendidikan, (2), 174-188.

Susanti, R., Sari, S. A., Milfayetty, S., \& Dirhamsyah, M. (2014). Hubungan Kebijakan, Sarana dan Prasarana dengan Kesiapsiagaan Komunitas Sekolah Siaga Bencana Banda Aceh. Jurnal Ilmu Kebencanaan (JIKA), $1(1), 42-49$.

Timothy, S. I. M., Dominelli, L., \& Jocelyn, L. A. U. (2017). a Pathway To Initiate Bottom-Up Community-Based Disaster Risk Reduction Within a Top-Down System: the Case of China. International Journal of Safety and Security Engineering, 7(3), 283-293. https://doi.org/10.2495/SAFE-V7-N3-283-293

Trainor, J. E., \& Velotti, L. (2013). Leadership in crises, disasters, and catastrophes. Journal of Leadership Studies, 7(3), 38-40. https://doi.org/10.1002/jls.21295

Walz, B. J. (1992). Disaster Training Exercises: An Educationally-Based Hierarchy. Prehospital and Disaster Medicine, 7(4), 386-388. https://doi.org/10.1017/S1049023X00039820

Wu, T., Takara, K., \& Yamashiki, Y. (2012). The vulnerability variation from government roles in disaster risk reduction plans for sediment disasters in Taiwan. Hydrological Processes 26, 26, 2421-2430.

Zhanghui, Y., \& Zhiming, B. (2011). Chinese disaster management institutional framwork: Problems and suggestions for improvement: Angle of inter-governmental relationships. International Conference on E-Business and E-Government, ICEE2011 - Proceedings, 4921-4924.

Zubir, S. S., \& Amirrol, H. (2011). Disaster risk reduction through community participation. WIT Transactions on Ecology and the Environment, 148, 195-206. https://doi.org/10.2495/RAV110191 